\title{
FORMULATION DEVELOPMENT AND CHARACTERIZATION OF SNAKEHEAD FISH POWDER IN ORAL DOUBLE EMULSION
}

\author{
ROBERT TUNGADI ${ }^{*}$, ARLAN K IMRAN ${ }^{a}$ \\ aDepartment of Pharmacy, Faculty of Sport and Health, State University of Gorontalo, Gorontalo, Indonesia \\ Email: rtungadi@yahoo.com
}

Received: 19 Dec 2017, Revised and Accepted: 13 Feb 2018

\begin{abstract}
Objective: Snakehead fish has been scientifically proven to increase levels of albumin and boost the immune system so that the formulation development is required. The objective of this study was to formulate and characterize snakehead fish powder (SFP) in the form of the oral double emulsion.

Methods: The manufacture of snakehead fish powder used the conventional method with dry heating at $50{ }^{\circ} \mathrm{C}$. Characterization of SFP utilized proximate analysis method per $3 \mathrm{~g}$ of SFP. The double emulsion preparation was carried out by mixing $30 \%$ of the primary emulsion (w/o) into $70 \%$ of the secondary emulsion $(\mathrm{w}$ ) to form the $\mathrm{w} / \mathrm{o} / \mathrm{w}$ emulsion. This preparation was prepared in 4 formulas having variations in Tween 80 concentrations at the secondary emulsions of $0.7 \%, 3.5 \%, 7.0 \%$ and $10.5 \% \mathrm{w} / \mathrm{v}$, respectively using the spontaneous emulsification method. After that, all formulations were doing some tests, i.e. organoleptic test, $\mathrm{pH}$, viscosity, flow types, globular diameter test and stability tests.

Results: The results of proximate analysis every $3 \mathrm{~g}$ of SFP have obtained the contents of protein, $16.89 \%$, lipid $24.52 \%$, water $1.73 \%$ and ash $1.05 \%$. Based on the optimization of the formula, the preparation of F4 with the content of Tween 80 at $10.5 \%$ secondary emulsion is the best formula due to slow phase separation, $\mathrm{pH} 7$, unchanged organoleptic properties, large internal and external globular diameter (6.35 $\mu \mathrm{m}$ and $8.9 \mu \mathrm{m})$, as well as having a high viscosity value (1569.84 p) which correspond to pseudo plastic flow.
\end{abstract}

Conclusion: The novelty of SFP can be developed as double emulsion orally based on the results of characterization and evaluation of double emulsion.

Keywords: Double emulsion, Powder, Snakehead fish, Tween 80

(C) 2018 The Authors. Published by Innovare Academic Sciences Pvt Ltd. This is an open-access article under the CC BY license (http://creativecommons.org/licenses/by/4.0/) DOI: http://dx.doi.org/10.22159/ijap.2018v10i2.24175

\section{INTRODUCTION}

Indonesia is an archipelago country which is rich in natural materials from marine plants and marine animals. One of them is Gorontalo Province, which has Limboto lake producing snakehead fish (Ophiocephalus striatus). It is a type of fish that live in freshwater and is widely known by the community [1].

In Gorontalo, Traditional medicine has been done by the community by boiling snakehead fish to obtain its extract, then drunk to patients who are malnourished or postoperative wounds after childbirth. Basically, the administration of the snakehead fish water extract to the patients is less favored so that many patients who do not like it. Therefore, previous researchers had made in the form of capsule preparations that are applied to post-surgical wound patients [2].

Nowadays pharmaceutical products of snakehead fish are developed by researchers in the form of cream preparations [1], capsule preparations [10] and suspension preparations [4]. According to Tungadi stated that SFP had been formulated into a macro emulsion cream for accelerating wound healing of post-operation in vitro. In general, this cream was physically unstable, so that the emulsion system was easily broken by adding the energy of oil, the water phase and storage temperature $[3,4]$.

Besides that, the giving of snakehead fish meat is not so favored because it has an unpleasant odor and has a high-fat content causing the process of degradation quickly and rancid smell. Therefore, this problem can be solved by formulation development in the form of the oral double emulsion. The double emulsion is a complex system, also known as the emulsion in the emulsion, in which the droplet of the dispersed phase itself also containing a smaller dispersed droplet, the double emulsion belonging to a simple emulsion with a general type of $w / o / w$ (water in oil in water) and o/w/o (oil in water in oil) [5]. One of the advantages of double emulsion orally can cover unpleasant odors of fish and maintain the stability of snakehead fish powder containing high protein and amino acids [6].

The preparation of oral, double emulsions of SFP is a new formulation that has never been done by previous researchers and also the manufacture of snakehead fish powder in double emulsion preparation having the challenge of the researcher to gain good quality in the oral formulation such as physical stability. This study was the development of snakehead fish dry extract, in which the oral, double emulsion preparation indicating as a dietary supplement to boost the immune system. Based on this background, that conducted research on the development of formulation and characterization of SFP in the oral double emulsion.

\section{MATERIALS AND METHODS}

\section{Materials}

Snakehead fish was gained from Limboto Lake, sodium carboxymethyl cellulose (Na CMC), tween 80, Butylhydroxytoluene (BHT), propylene glycol, Span 60 , sodium saccharin, and olive oil were bought from PT. Intraco Pharmaceuticals. All other ingredients used were of analytical grade. Homogenizer IKA T25 Digital, electrical stove (Maspion), Viscometer Brookfield (DV-E Viscometer), oven (Memmert, Germany), water bath (Memmert, Germany), polarization microscopy (Olympus).

\section{Making snakehead fish powder}

In the manufacture of snakehead, the fish powder was utilized 5 snakehead fish which obtained from Limboto Lake, Gorontalo Province. The first stage was to clean 5 snakehead fish by removing fish's belly and mucus. The meats of snakehead fish were sliced in dice and steamed at $50{ }^{\circ} \mathrm{C}$ for $15 \mathrm{~min}$ using a weight ratio of fish with the water volume of 1 : $1 / 3[7,8]$. Furthermore, fish meat with skin and bone were separated and crushed by using a blender to obtain a homogeneous paste of fish meat. The next stage, the homogeneous paste was dried by stratified drying at $60^{\circ} \mathrm{C}$ for $30 \mathrm{~min}$. Then the temperature was gradually lowered to $50^{\circ} \mathrm{C}$ for $1 \mathrm{~h}$ until the water content did not exceed $10 \%$ [9]. After that, the result was gained a rough powder of Snakehead fish and continued by grinding the powder several times and sieved on a 100 mesh to obtain a fine powder of SFP [10].

\section{Characterization of snakehead fish powder}

The powder of snakehead fish that had been made then tested the proximate level, including the test of protein, lipid, water and ash content. 


\section{Preparation of SFP in double emulsion orally}

This formulation was made 4 formulas using different concentrations of tween 80 as secondary emulsion i.e. F1 0.7\%, F2.3.5\%, F3 7.0\%, and F4 $10.5 \% \mathrm{w} / \mathrm{v}$.

\section{Formulation of primary emulsion w/o of SFP}

The first, double emulsion w/o/w type was initiated by making primary emulsion w/o by dissolving the snakehead fish powder into olive oil as the oil phase in the primary emotion. Then span 60 was melted and added BHT into the oil phase, stirred to make homogeneous. After that, a solution of tween 80 and sodium saccharin was prepared as a water phase, stirred until homogeneous dispersion and poured water phase slowly into the oil phase. The final stage was a homogenized mixture of both emulsion phases used homogenizer at $6000 \mathrm{RPM}$ for $30 \mathrm{~min}$ [21].

\section{Formulation of double emulsion $w / o / w$ of SFP}

After the primary emulsion was formed, the first stage was the preparation of the double emulsion by swelling of $\mathrm{Na} \mathrm{CMC}$ in water for the secondary emulsion for $24 \mathrm{~h}$. After that, Na CMC dispersion was stirred while adding tween 80 and propylene glycol until homogeneous. Lastly, the primary emulsion was added gradually into the water phase mixture of the secondary emulsion while stirring using homogenizer at 3000 RPM till homogeneous emulsion [22]

\section{Evaluation of SFP double emulsion}

\section{The organoleptic test}

The Organoleptic observation was done by observing the taste, aroma, and appearance of the double emulsion from week 0 to week 4 .

Table 1: The composition of snakehead fish double emulsion

\begin{tabular}{|c|c|c|c|c|}
\hline \multirow[t]{2}{*}{ Materials } & \multicolumn{4}{|c|}{ Concentration (\%) } \\
\hline & F1 & F2 & F3 & F4 \\
\hline \multicolumn{5}{|l|}{ Primary Emulsion (w/o) } \\
\hline Snakehead fish powder & 3 & 3 & 3 & 3 \\
\hline Olive Oil & 10.5 & 10.5 & 10.5 & 10.5 \\
\hline Span 60 & 2.62 & 2.62 & 2.62 & 2.62 \\
\hline Tween 80 & 0.3786 & 0.3786 & 0.3786 & 0.3786 \\
\hline Water & 12.88 & 12.88 & 12.88 & 12.88 \\
\hline \multicolumn{5}{|c|}{ Secondary Emulsion (w/o/w) } \\
\hline Tween 80 & 0.7 & 3.5 & 7.0 & 10.5 \\
\hline $\mathrm{Na} \mathrm{CMC}$ & 1.05 & 1.05 & 1.05 & 1.05 \\
\hline Propylene glycol & 10.5 & 10.5 & 10.5 & 10.5 \\
\hline Water & 57.75 & 54.25 & 50.75 & 47.25 \\
\hline
\end{tabular}

\section{pH test}

The $\mathrm{pH}$ test was performed by $\mathrm{pH}$ meter. The electrode was immersed in an emulsion preparation. The $\mathrm{pH}$ appeared on the screen and was stable then recorded. Measurements were made at room temperature. This $\mathrm{pH}$ test was conducted from week 0, 1, 2, 3 and week 4 [11].

\section{Viscosity test}

The viscosity test was performed using a Brookfield Viscometer. The preparation was stored in a beaker glass, then the spindle is lowered into the preparation to the specified limit and the spindle rate was set at 30 RPM. Observations were made from week 0 to week 4 [19].

\section{Flow type test}

The flow type test was performed by Brookfield Viscometer. The preparation was stored in the beaker glass, then the spindle was lowered into the preparation to the specified limit, the speed was set from $5,10,20,50$, and $100 \mathrm{RPM}$, and proceeded from the reverse velocity $100,50,20,10$, and 5 RPM. The viscosity value was gained to calculate the shear stress $\left(\mathrm{dyne} / \mathrm{cm}^{2}\right)$. Shear pressure and shear rate (RPM) were poured in a theological pattern. This type of flow test was performed only at week 0 [20].

\section{Average globular diameter test}

The average globular diameter was measured by the polarizing microscope, which equipped with a calibrated ocular lens and micrometre. The double emulsion was placed on the object glass and covered with glass. Then it was observed using a microscope at 200 times magnification. The observed images were photographed and measured the globule diameter. The average globule diameter test was performed at weeks 0 and 4 [18].

\section{Stability study}

Stability studies were carried out for the formulation of snakehead fish powder, the double emulsion as per ICH guidelines at $40 \pm 4{ }^{\circ} \mathrm{C}$. Thermodynamic stability of prepared double emulsion formulation was assessed by stability under centrifugation and Freeze-Thaw cycles $[12,17]$.

\section{Statistical analysis}

Data on the relationship between each formulation and the obtained results of physical evaluation were analyzed by one way ANOVA (Analysis of Variance) method using SPSS 16.

\section{RESULTS}

\section{Proximate analysis of SFP}

In the processing of snakehead fish powder, quality control is a requirement that must be fulfilled. One of the determinations of the quality of snakehead fish powder and its relation to the objective requirement on nutritional value can be done through analysis of proximate level. Proximate analysis is a rough analysis, including the total amount of ash, water, fat and protein content. The results of proximate analysis of SFP can be seen in table 2. The formulations of SFP in double emulsion the amount of powder which used for each preparation was $3 \mathrm{~g}$. The results of the analysis of protein, lipid, water and ash content that has been converted per $3 \mathrm{~g}$ of SFP can be seen in table 3. This becomes the reference in determining the concentration used in the preparation. The protein content in $3 \mathrm{~g}$ of the powder has been used as one of the additional protein sources to meet the individual protein requirement. The human protein requirement per day should not be less than 0.6-0.7 g protein per kilogram of body weight [13].

\section{Evaluation of SFP double emulsion}

\section{The organoleptic test}

All formula (F1-F4) did not show the changes in color, taste, and flavor from week 0 to week 4 which marked each formula gave yellowish white, lemon flavor and sweetness.

\section{pH test}

The $\mathrm{pH}$ test was performed from week 0 to week 4 on each of the oral, double emulsion of snakehead fish powder. The $\mathrm{pH}$ of all formulas until the 4th week, was stable at $\mathrm{pH} 7$ (fig. 1). This double emulsion formula was made in $\mathrm{w} / \mathrm{o} / \mathrm{w}$ with the amount of water was more than the oil, so the $\mathrm{pH}$ of each formula followed the $\mathrm{pH}$ of the water (neutral). This $\mathrm{pH}$ is highly desirable because it corresponds to the stability of the active compounds that was stable at the neutral $\mathrm{pH}$. 
Table 2: The proximate analysis of SFP

\begin{tabular}{lllll}
\hline No.Unit & Sample & Sample weight & Parameter test & Analysis result \\
\hline 1. & SFP\% & $1 \mathrm{~g}$ & protein & $5.6032 \pm 1.51$ \\
& $1 \mathrm{~g}$ & & $5.6032 \pm 0.85$ \\
& $1 \mathrm{~g}$ & lipid & $5.6908 \pm 0.76$ \\
2. & $5 \mathrm{~g}$ & & $40.2 \pm 0.56$ \\
& $5 \mathrm{~g}$ & $5 \mathrm{~g}$ & $40.6 \pm 0.84$ \\
& & $5 \mathrm{~g}$ & water & $41.8 \pm 0.89$ \\
3. & $5 \mathrm{~g}$ & content & $2.8659 \pm 1.25$ \\
& & $5 \mathrm{~g}$ & ash content & $2.8675 \pm 0.65$ \\
& & $5 \mathrm{~g}$ & & $2.9089 \pm 0.46$ \\
& & $5 \mathrm{~g}$ & & $1.7660 \pm 0.97$ \\
& & $5 \mathrm{~g}$ & & $1.7580 \pm 1.35$ \\
\end{tabular}

All values are reported as mean \pm SD (n=3); SD: Standard Deviation; SFP: Snakehead Fish Powder

Table 3: The proximate analysis each $3 \mathrm{~g}$ of SFP

\begin{tabular}{lll}
\hline No. & Parameter test & Analysis result (\%) \\
\hline 1. & Protein & $16.897 \pm 0.55$ \\
2. & Lipid & $24.520 \pm 0.68$ \\
3. & Water content & $1.7284 \pm 0.87$ \\
4. & Ash content & $1.0528 \pm 1.14$ \\
\hline
\end{tabular}

All values are reported as mean \pm SD $(n=3)$

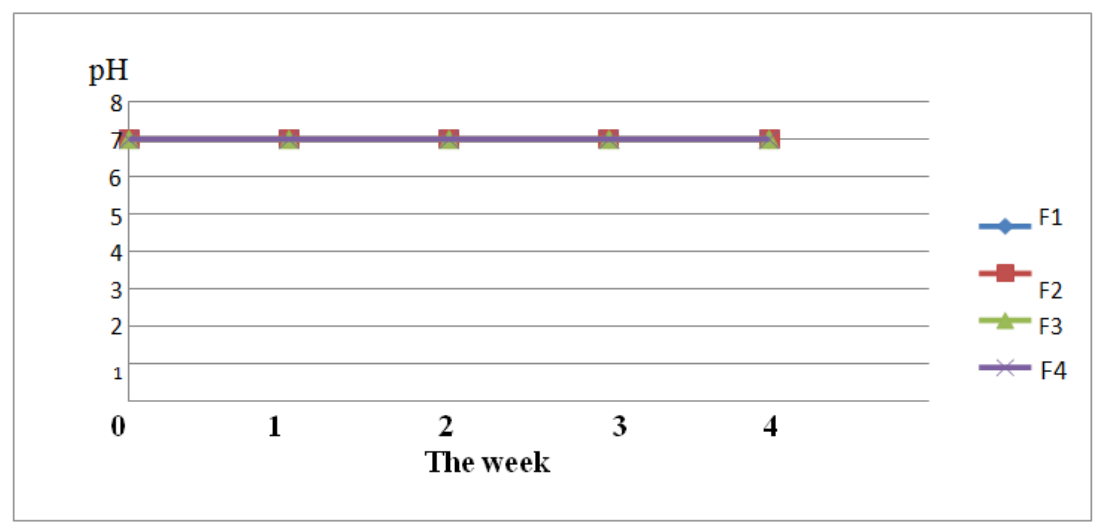

Fig. 1: The pH curve of snakehead fish powder double emulsion

\section{Viscosity test}

The viscosity test was performed from week 0 to week 4 using a spindle of Brookfield Viscometer number 3 at speed 30 RPM. The data showed that the highest viscosity was owned by formula 4 as shown in table 4 and fig. 2 .

Due to CMC sodium use in formula causes as viscosity enhancing agent which will slow down the incorporation of droplets. Besides that, Tween 80 can also increase the viscosity in various concentrations. Because Tween 80 has nonionic surfactant molecule having a long chain of the hydrophilic group which is the highest concentration of the Tween 80, the long hydrophilic group is formed and form the molecular layer on the droplet surface which will prevent incorporation of droplets and increase the viscosity of the formula [15]. However, there is a decrease in viscosity of all formulas as a whole along with increasing storage time. Because the long chains which owned by Tween 80 begin to break down the molecule chain due to oxidation and so on. In addition, the decrease of viscosity is also due to the coalescence of the internal phase, i.e. water droplets with the external continuous water phase [16]. This case can be seen from the size of the internal and the external droplet at week 4 which was diminishing.

Table 4: The viscosity of double emulsion formulas

\begin{tabular}{lllll}
\hline The week & Formula viscosity & & & \\
\cline { 2 - 5 } & F1 $^{* *}$ & F2 $^{* *}$ & F3 $^{* *}$ & $1316.54 \pm 0.8$ \\
\\
\hline 0 & $1226.54 \pm 0.2$ & $1286.54 \pm 0.6$ & $1303.20 \pm 0.45$ & $1569.84 \pm 0.6$ \\
1 & $1203.80 \pm 0.3$ & $1271.50 \pm 0.3$ & $1288.54 \pm 0.5$ & $1543.10 \pm 0.3$ \\
2 & $1194.55 \pm 0.25$ & $1240.88 \pm 0.2$ & $1271.21 \pm 0.4$ & $1537.18 \pm 0.6$ \\
3 & $1171.88 \pm 0.45$ & $1226.88 \pm 0.35$ & $1216.88 \pm 0.25$ & $1532.18 \pm 0.7$ \\
4 & $1134.89 \pm 0.5$ & $1176.22 \pm 0.7$ & $1510.85 \pm 0.8$ \\
\hline
\end{tabular}

${ }^{* *} \mathrm{P}<0.01$; mean $\pm \mathrm{SD}, \mathrm{n}=3$ 


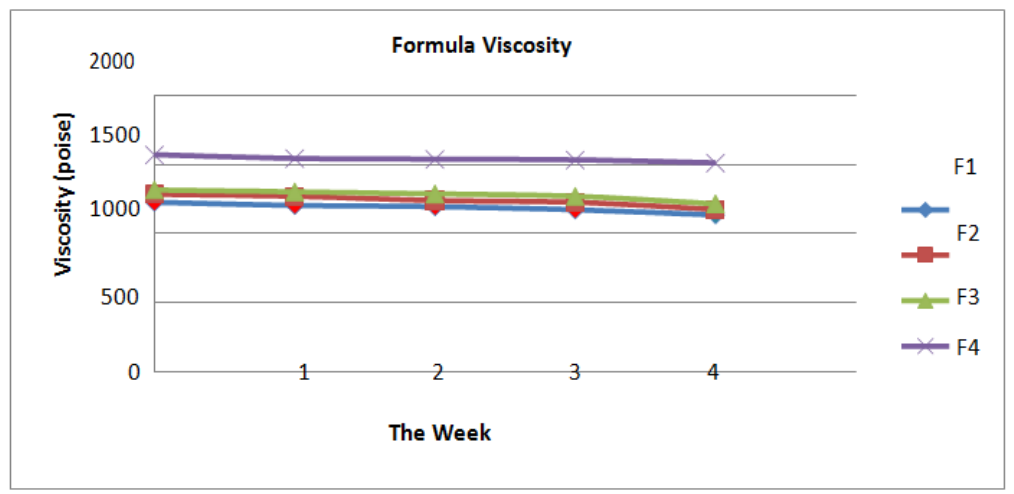

Fig. 2: The viscosity of snakehead fish double emulsion from the week 0 to 4

\section{Flow type test}

Testing of flow properties relates to casting when it is to be used.
The result of the test of flow characteristics of a double emulsion of SFP can be seen in fig. 3 and 4. The flow of all formulas showed the same flow character of the week 0 to 4 i.e. pseudoplastic flow.

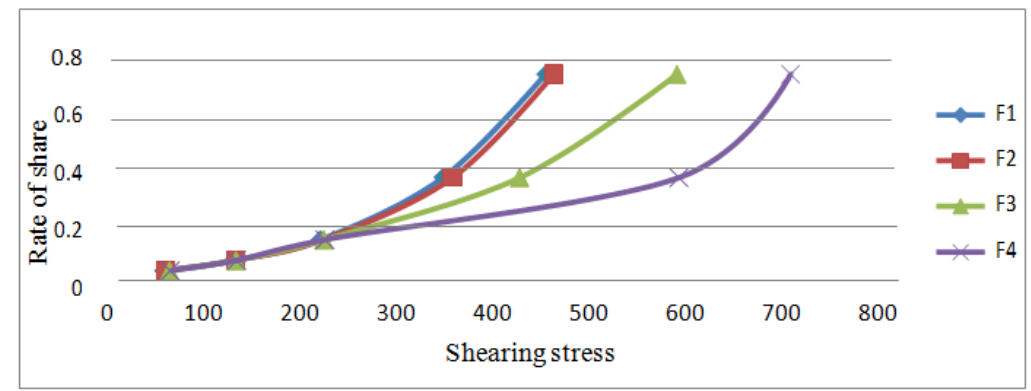

Fig. 3: The rheogram of double emulsion of SFP on the week 0

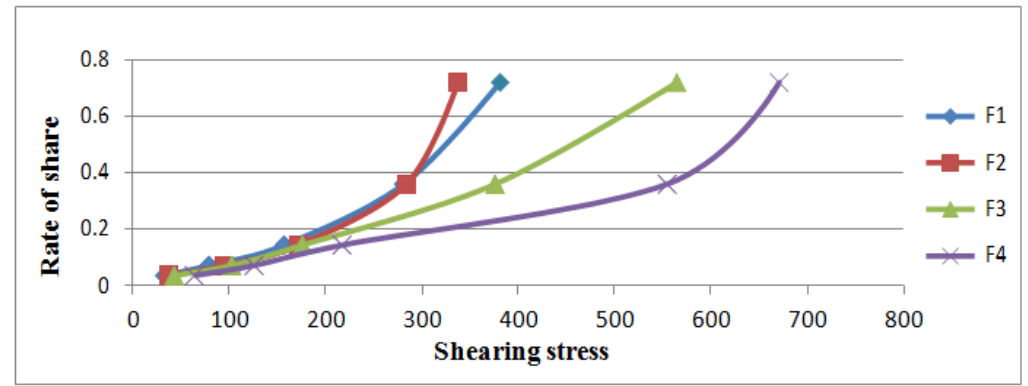

Fig. 4: The rheogram of double emulsion of SFP

\section{At the week 4}

The graphs showed all formulas for week 0 and week 4 described pseudoplastic flow which caused by the use of $\mathrm{Na} \mathrm{CMC}$. It has pseudoplastic flow properties which can be seen in the fig. which started from the point 0.0 and showed that the dosage is thicker when tested at 5 RPM, 10 RPM, 20 RPM, 50 RPM, and 100 RPM. However, when tested at opposite velocities, it was obtained that the viscosity was getting thinner.

\section{Average globular diameter test}

The measurement of the average globular diameter was to see the droplet stability of a double emulsion of snakehead fish powder as shown in table 5 which performed on the external and internal globules using a microscope with a micrometer at 200 times magnification.

Table 5: The average of globular diameter measurement

\begin{tabular}{|c|c|c|c|c|}
\hline \multirow[t]{2}{*}{ Formula } & \multicolumn{4}{|c|}{ The average of globular diameter $(\mu \mathrm{m})$} \\
\hline & External globular & & Internal globular & \\
\hline S. No. & The week 0 & The week 4 & The week 0 & The week 4 \\
\hline 1 & $5.565 \pm 0.56$ & - & $3.50 \pm 2.35$ & - \\
\hline 2 & $6.82 \pm 0.78$ & - & $4.95 \pm 1.67$ & - \\
\hline 3 & $7.40 \pm 1.56$ & - & $4.96 \pm 2.40$ & - \\
\hline 4 & $8.90 \pm 2.45$ & $6.01 \pm 0.57$ & $6.35 \pm 1.76$ & $4.72 \pm 2.57$ \\
\hline
\end{tabular}

All values are reported as mean \pm SD $(n=3)$. 
According to Fatimah stated that oil-in-water emulsions (secondary) can be formed when using surfactants with high HLB values such as Tween 80 (HLB 15). Meanwhile, in her study comparing the use of Tween 80 with a concentration of $0.5 \%, 1 \%$ and $1.5 \% \mathrm{w} / \mathrm{v}$, it was found that the use of Tween 80 at a concentration of $0.5 \%$ and $1 \%$ had not been able to form an o/w type emulsion (secondary). While at the concentration of $1.5 \%$ formed emulsion type $\mathrm{o} / \mathrm{w}$ (secondary) with the size of globular

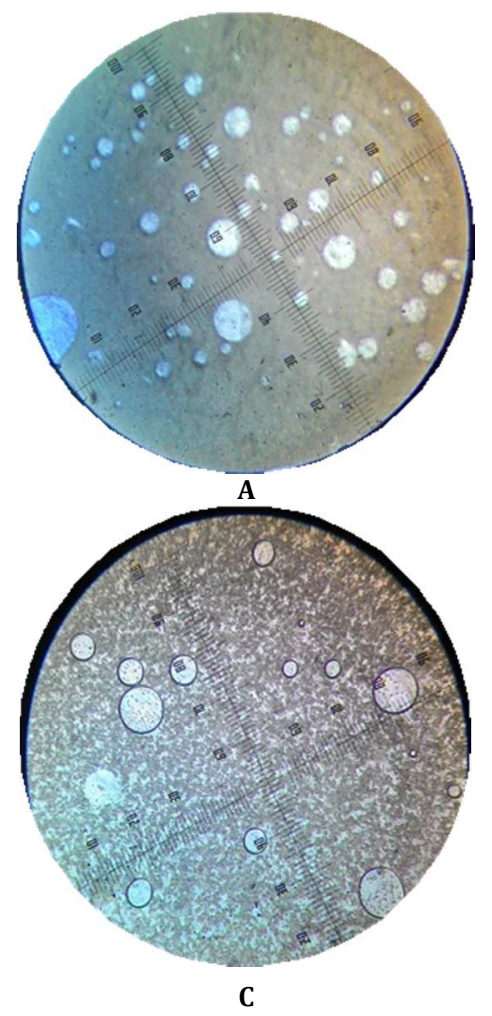

Fig. 5: The picture of globular diameter each formula the week 4, (A): a droplet of F1; (B): F2; (C): F3; (D): F4 diameter 1-5 $\mu \mathrm{m}$. This is related to the obtained results, which indicates that the higher Tween 80 concentration used (F4) in the $\mathrm{o} / \mathrm{w}$ type secondary emotion, the greater average globular diameter as shown in fig. 5. However, the average globular diameter decreased during the week 4 . This corresponds to the double emulsion instability of coalescence between the inner and outer liquid phases marked by a decrease in the average size of the globular diameter of formula [16].
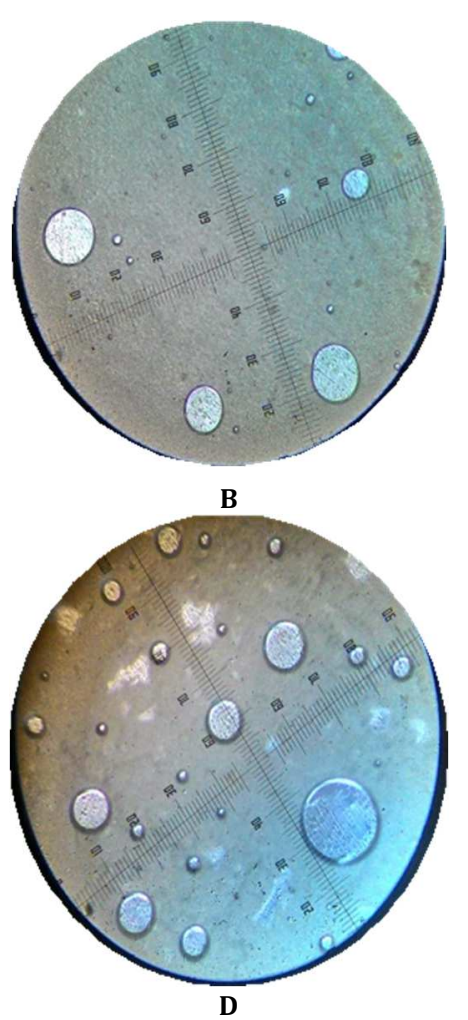

\section{Stability study}

Based on stability test, all formulas of SFP, double emulsion showed different results on Freeze-Thaw test which consisted of 7 cycles. The last cycle of Freeze-Thaw test showed phase separation which measured the phase separation height, i.e. F1 $(0.4 \mathrm{~cm}), \mathrm{F} 2(0.7 \mathrm{~cm})$, F3 $(0.6 \mathrm{~cm})$ and F4 $(0.1 \mathrm{~cm})$. The best formula was F4 due to slow phase separation, no $\mathrm{pH}$ changes and organoleptic properties, large external and internal globular diameter, high viscosity and pseudoplastic flow as expected.

Based on statistical analysis with One Way ANOVA, it was found that there was a significant relationship between the variations of Tween 80 concentration on the formula on the viscosity of the preparation. This was indicated by a significant value which was smaller than the value of $\alpha(\alpha=0.01)$.

\section{DISCUSSION}

Snakehead fish powder (SFP) is one of freshwater fish containing active compounds such as hydrophilic and lipophilic compounds which consist of protein, albumin, amino acids and arachidonic acid. The most components in SPF are lipid $24.52 \%$ and protein $16.89 \%$, which are both of them can boost the immune system in the human body. Besides that, SPF has poorly water-soluble compounds which are difficult to be absorbed by gastrointestinal. Therefore, SPF was formulated into double emulsion orally.

Double emulsions are complex systems in which the droplets of the dispersed phase themselves contain small dispersed droplets. There are two types of double emulsions, water-in-oil-in-water $(\mathrm{w}=\mathrm{o}=\mathrm{w})$ and oil-in-water-in-oil $(\mathrm{o}=\mathrm{w}=0)$. Due to their multi-compartment structure, these systems have many applications in the pharmaceutical, cosmetic, and food industries [21]. These emulsions are thermodynamically unstable. However, they can be kinetically stable over a significant period, which determines their uses. This stability can be performed by macromolecules of synthetic surfactants.

In most studies double emulsions are prepared in a two-step emulsification process by two sets of emulsifiers; a hydrophobic emulsifier designed to stabilize the interface of the water-in-oil internal emulsion and a hydrophilic emulsifier for the external interface of the oil-in-water emulsion. The primary w/o emulsion is prepared under high-shear conditions while the secondary emulsification step is normally carried out without severe shear to avoid rupture of the internal droplets. The composition of the multiple emulsion components is of significant importance to the stability and release properties. Much work has been carried out on optimizing the nature of the oils, the weight fractions of the water and the oil, and the nature of the surfactants. Ionizing and non-ionic low molecular weight surfactants have traditionally been used as emulsifiers stabilizing double emulsions for food, cosmetic and pharmaceutical applications, in accordance with health restrictions. It was, however, well established that combinations of emulsifiers, at the outer phase, have a beneficial effect on stability, and that the inner hydrophobic emulsifiers must be used in great excess (10-30 weight $\%$ of the inner emulsion) while the hydrophilic emulsifiers must be used in low concentration (0.5-5 weight \%). The inner emulsifier was found to migrate in part through the oil lamellae to the outer interface and to influence it [22]. This is accordance with the methods which utilized in this study, i.e. emulsification method using primary emulsion and secondary emission. 
According to Seddari, et al. (2013) stated that the emulsions made at $\mathrm{pH} 5$ showed a better stability compared to those made at natural $\mathrm{pH}$. The optimal $\mathrm{pH}$ for the formulation of these double emulsions is 5 . Knowing that multiple emulsions are very unstable systems, this study showed that it is possible to prepare stable double emulsions for a considerable time using a mixture of protein and polysaccharide [21].

Otherwise, the results of this study showed all formulations had a $\mathrm{pH}$ neutral 7 accordances with a pH of SFP active compounds which was stable in $\mathrm{pH}$ neutral. If this is in the condition of acid or base solutions, this will cause the protein to settle in the solution [14]. Based on the obtained results showed the adding of tween 80 did not affect $\mathrm{pH}$ of a double emulsion of SFP. It means that the stability of double emulsions depends on $\mathrm{pH}$ of active compounds. The viscosity test is related to rheology properties to determine the flow type of dosage forms. In this study showed F4 was the best viscosity having the viscosity mean around $1538.63 \pm 0.6$. This means that the higher the concentration of surfactant (tween 80) used, then the thicker the formula. This is consistent with Seddari that the viscosity of double emulsions depends on that of the outer phase, which is a function of XG concentration. These results are in agreement with the results obtained in a previous work for the stabilization of emulsions with SC-XG mixture at the natural $\mathrm{pH}(\mathrm{pH} 7)$. Moreover, the viscosity profiles also showed that the apparent viscosity decreases with increasing shear rate, which proves that the formulated emulsions are non-Newtonian fluids [21]. Meanwhile, the flow type of SFP double emulsion can be seen from graph 3 and 4 showed pseudoplastic flow because in the formulation used Na CMC to increase the viscosity of the double emulsion. Regarding this, each formula had a rate of share and shearing stress to determine the type of flow. Obviously, the infinite-shear limit is not seen for polymer melts and blends, or foams or emulsions or suspensions. Thus, the apparent viscosity of a pseudoplastic substance decreases with the increasing shear rate [22].

\section{CONCLUSION}

The characterization of snakehead fish powder from the proximate analysis has obtained the contents of protein, $16.89 \%$, lipid $24.52 \%$, water $1.73 \%$ and ash $1.05 \%$.

The Snakehead fish powder can be formulated into double emulsion showing good stability for Formula 4 containing the highest concentration of tween 80 in the secondary emulsion.

\section{ACKNOWLEDGEMENT}

The authors are thankful to The Institute of Education Funds Management (LPDP) giving sponsor to publish this paper. Besides that, we also thank to Dean of Pharmacy Faculty, Hasanuddin University and staffs giving excellent technical support.

\section{AUTHORS CONTRIBUTIONS}

All the authors have contributed equally

\section{CONFLICTS OF INTERESTS}

All authors have none to declare

\section{REFERENCES}

1. Tungadi R, Attamimi F, Firmina S, Nugraha E. The acceleration of wound healing of snakehead fish cream towards rabbit's skin wound histopathologically. Indo Pharm J 2011;9:91-7.
2. Tungadi R, Wicita P. Formulation, characterization and optimization of snakehead fish (Ophiocephalus striatus) powder nanoemulgel. Int J Pharm 2017;7:38-43.

3. Tungadi R, Mozin RW. Characterization and physical stability evaluation of snakehead fish (Ophiocephalus striatus) nanoemulsion. Int J Pharm Sci Res 2017;8:1000-6.

4. Lawang AT. The making of snakehead fish (Ophiocepahalus striatus) Concentrate Dispersion as Food Supplement. The Agriculture Faculty. Hasanuddin University. Makassar; 2013.

5. Kumar R, Kumar MS, Mahadevan N. Multiple emulsions: a review. Int J Recent Adv Pharm Res 2012;2:9-19.

6. Garti N, Aserin A. Double emulsion stabilized by macromolecular surfactant. J Adv Colloid Interface Sci 1996;65:37-69.

7. Sulthoniyah STM. The effect of temperature measurement against the content of nutrition and appearance of snakehead fish meat. J Stud Agric Tech 2013;1:33-45.

8. Hou W, Papadopoulos KD. W1/0/W2 and 01/W/02 globules stabilized with span 80 and tween 80 . Colloids and Surfaces. I Physicochem Eng Aspects 1997;125:181-7.

9. Swarbrick J. Encyclopedia of pharmaceutical technology. $3^{\text {rd }}$ ed. Vol 1. New York: Informa Healthcare USA; 2007.

10. Tawali AB. The technology diffusion of protein concentrate production of snakehead fish as a food supplement in Jayapura. Hasanuddin University. Makassar; 2012.

11. Mason TJ, Wilking JN, Meleson K, Chang CB, Graves SM. Nanoemulsions: formation, structure and physical properties. J Phys-Condens Matter 2006;18:636-43.

12. Nagendra R, Roopa SP, Gurinder S. Design and optimization of the novel in situ gel of mercaptopurine for sustained drug delivery. Brazilian J Pharm Sci 2014;50:107-19.

13. Meyers D. Surfactant Science and Technology. John Willey and Sons (NJ) Inc; 2006.

14. Underwood RA. The analysis and quantitative chemistry. Jakarta: Erlangga Publisher; 2001.

15. Fatimah $\mathrm{F}$. The quality of salad dressing emulsion made from virgin coconut oil. J Agritech 2011;31:56-60.

16. Jiahong S. Formulation and Stability of Food Grade Water in Oil in Water Emulsion. Thesis of Food Technology. Ridder Institute Massey University. New Zealand: Palmerston North; 2008.

17. Iradhati $\mathrm{AH}$, Jufri M. Formulation and physical stability test of griseofulvin microemulsion gel. Int J Appl Pharm 2017;9:23-6.

18. Tatar V, Mootse H, Sats A, Kaart T, Poikalainen V. Evaluation of the size distribution of fat globules and fat and protein content in Estonian goat milk. Agro Res 2015;13:1112-9.

19. Deveda P, Jain A, Vyas N, Khambete H, Jain S. Gel liquid emulsion for sustain delivery of itraconazole for topical fungal diseases. Int J Pharm Pharm Sci 2010;2:104-12.

20. Yati K, Srifiana Y, Putra F. Effect of optimization of tween 80 and propylene glycol as a surfactant and cosurfactant on the physical properties of aspirin microemulsion. Int J Appl Pharm 2017;9:127-9.

21. Seddari S, Mostefa NM. Formulation and characterization of a double emulsion stabilized by sodium caseinate-xanthan mixtures effect of $\mathrm{pH}$ and biopolymer concentration. J Dispersion Sci-Tech 2013;36:51-60.

22. Garti N, Bisperink C. Double emulsions: progress and applications. Curr Opin Colloid Interface Sci 1998;3:657-67. 